\title{
Editorial: I Keep My Eyes Wide Open All the Time
}

It's a Sunday morning-a little after 10 A.M. I'm on a crosscountry flight to Boston to attend the fall meeting of the ARL MetaLib Implementor's Group (playfully known as ARMPIG) chaired now by Roy Tennant. It must be time to write an ITAL editorial.

I have had an idea to write about the challenges and experiences I have found during my first year as editor. Of course the writing of an editorial itself is a challenge. Founding Editor Fred Kilgour never wrote editorials so why should I and some of his successors presume the necessity? This particular editorial is even more of a challenge because the key cap that contains the comma is suddenly missing from my laptop. It was there sometime yesterday or at least a couple of days ago. I've looked all around my seat-imagine how ridiculous a passenger crawling around on the floor of a nearly full Boeing 737 looks. Imagine how ominous he looks crawling when he is no further than a short jump shot-just outside the first class line-from the crew compartment. I may have to finish this from a prison cell.

This first year actually began in July 2004 when Managing Editor Marc Truitt and I spent part of a day at ALA headquarters in Chicago being oriented by Kristen McKulski of ALA Production Services. The deadline to send my first issue-March 2005-was November 23! That was eyeopener number one. Manuscripts forwarded by then-editor Dan Marmion began to arrive on my doorstep and in my e-mail within days thereafter.

I learned in orientation that ALA has no article management software to help editors track the flow of the editorial process. Each editor has to devise the systems to ingest articles; to acknowledge their receipt and provide feedback to authors about everything from time frames to changes required or suggested by the referees and editor; to accept or reject articles; to manage the flow of the refereeing process; and to package the edited manuscripts and auxiliary information that are submitted as an issue to ALA Production Services. That was the second eyeopener. And I'm now using my second homegrown system. I dumped the inadequate first and started again from scratch sometime before the third issue. I suspect I may modify it or develop a third sometime this year.

I steeled myself at the beginning for the defensiveness that authors would reasonably adopt when confronted with the often extensive changes recommended by the referees and me. As a referee I had read one published article by a well-known author that contained none of my worthy advice. Some of our authors are almost certainly much better "known" than some of our referees. But authors instead have been unanimously grateful for the feedback. Only one article published in volume 24 required no changes. The changes in one or two others were minimal. Others required multiple rewrites. Our acceptance rate has been 45 percent so far. Some authors whose articles were rejected have thanked me for considering them. Eyeopener number three.

The work performed by ALA Production Services in transforming the Word documents and any accompanying illustrations that I submit into a digital file that looks for all the world like a real journal issue astonished me. I literally jumped in my seat when I opened the PDF file that represented the first pass of my first issue! I can compare it only to the experience of stepping out into a cloudand moonless night in a place unpolluted by the ambient lighting and air pollution of modern civilization and being startled by the vividness of the starry night sky. I get to experience the latter somewhat regularly because I live in the Pacific Northwest. I get to experience the former once a quarter. An appropriate fourth eyeopener. I like both.

The amount of work performed by Marc Truitt in transforming the first pass by working with authors on wording changes and footnote styles and illustration titles and placements and table clarification and grammar and punctuation and capitalization and who knows what else is enormous and was totally unanticipated by me. This is way-big eye-opener number five. (In fact with this first issue of 2006 I have tried to pay more wide-eyed attention to the copy I sent to allay some of his work.) Marc's collaboration with ALA Production Services and the authors produces the issues you read. The goal is that the second pass will require no or only minor changes. Writing this paragraph has given me another idea: Marc should write an editorial about the job of the ITAL managing editor. My only fear is that his description will be such an eyeopener to the membership that we'll never find a successor when he decides he has paid his dues!

I asked myself when I agreed to be nominated for this post if I were walking into it with my eyes wide shut. I asked the same question as I walked down a long hall to the LITA Publications Committee meeting at ALA Midwinter 2004 to be interviewed. I asked again after the interview. It was too late to ask the question again after I received the offer: I had already crossed too many lines in the sand. But my one-and-a-half-year-long first year has been eyeopeningly fun and rewarding. My eyes seem as open as they've been for the past few decades. I don't mind soliciting potential authors for articles. I find that I can beg shamelessly. I seem to have a good rapport with most authors. The ITAL board gives me no respect. You should all thank them for that.

Are your eyes open? Did you notice this editorial is comma-less? We're about an hour from Boston now. Will I soon be on my way to my hotel or my prison cell? Keep your eyes open for the next ITAL issue.

John Webb (jwebb@wsu.edu) is Assistant Director for Systems and Planning, Washington State University Libraries, Pullman, and Editor of Information Technology and Libraries. 